\title{
ESSENTIAL NORM OF WEIGHTED COMPOSITION OPERATORS ON ZYGMUND-TYPE SPACES WITH NORMAL WEIGHT
}

\author{
JUNTAO DU, SONGXIAO Li AND YANHUA ZHANG
}

Abstract. In this paper, we investigate the boundedness, compactness and essential norm of weighted composition operators between Zygmund-type spaces with normal weight.

Mathematics subject classification (2010): 47B33, 30H10.

Keywords and phrases: Weighted composition operator, Bloch-type space, Zygmund-type space, boundedness, compactness, essential norm.

\section{REFERENCES}

[1] B. Choe, H. Koo And W. Smith, Composition operators on small spaces, Integral Equations Oper. Theory 56 (2006), 357-380.

[2] F. COLOnNA, New criteria for boundedness and compactness of weighted composition operators mapping into the Bloch space, Cent. Eur. J. Math. 11 (2013), 55-73.

[3] F. COLONNA AND S. LI, Weighted composition operators from the Lipschitz space into the Zygmund space, Math. Inequal. Appl. 17 (2014), 963-975.

[4] C. Cowen And B. Maccluer, Composition Operators on Spaces of Analytic Functions, CRC Press, Boca Raton, FL, 1995.

[5] J. DU AND S. LI, Weighted composition operators from Zygmund-type spaces to Bloch-type spaces, Math. Inequal. Appl. 20 (2017), 247-262.

[6] J. DU AND X. ZHU, Generalized composition operators on Zygmund-type spaces and Bloch-type spaces, J. Comput. Anal. Appl. 23 (2017), 635-646.

[7] K. ESMAEILI AND M. LINDSTRÖM, Weighted composition operators between Zygmund type spaces and their essential norms, Integral Equations Oper. Theory 75 (2013), 473-490.

[8] Z. Hu, Composition operators between Bloch-type spaces in the polydisc, Sci. China 48A (supp) (2005), 268-282.

[9] Z. HU AND S. WANG, Composition operators on Bloch-type spaces, Proc. Royal Soc. Edinburgh 135 (2005), 1229-1239.

[10] O. HYVÄRINEN AND M. LINDSTRÖM, Estimates of essential norm of weighted composition operators between Bloch-type spaces, J. Math. Anal. Appl. 393 (2012), 38-44.

[11] S. Li AND S. STEVIĆ, Volterra type operators on Zygmund spaces, J. Inequal. Appl. vol. 2007 (2007), Article ID 32124, 10 pages.

[12] S. Li And S. STEVIĆ, Weighted composition operators from Zygmund spaces into Bloch spaces, Appl. Math. Comput. 206 (2008), 825-831.

[13] S. LI AND S. STEVIĆ, Generalized composition operators on Zygmund spaces and Bloch type spaces, J. Math. Anal. Appl. 338 (2008), 1282-1295.

[14] S. Li AND S. STEVIĆ, Products of Volterra type operator and composition operator from $H^{\infty}$ and Bloch spaces to the Zygmund space, J. Math. Anal. Appl. 345 (2008), 40-52.

[15] S. Li AND S. STEVIĆ, Integral-type operators from Bloch-type spaces to Zygmund-type spaces, Appl. Math. Comput. 215 (2009), 464-473.

[16] S. Li And S. STEvić, On an integral-type operator from $\omega$-Bloch spaces to $\mu$-Zygmund spaces, Appl. Math. Comput. 215 (2010), 4385-4391.

[17] S. Li AND S. STEVIĆ, Products of composition and differentiation operators from Zygmund spaces to Bloch spaces and Bers spaces, Appl. Math. Comput. 217 (2010), 3144-3154. 
[18] B. MACCLUER AND R. ZHAO, Essential norm of weighted composition operators between Bloch-type spaces, Rocky. Mountain J. Math. 33 (2003), 1437-1458.

[19] K. MAdigAn And A. Matheson, Compact composition operators on the Bloch space, Trans. Amer. Math. Soc. 347 (1995), 2679-2687.

[20] J. MANHAS AND R. ZHAO, New estimates of essential norms of weighted composition operators between Bloch type spaces, J. Math. Anal. Appl. 389 (2012), 32-47.

[21] S. Ohno, K. Stroethoff And R. Zhao, Weighted composition operators between Bloch-type spaces, Rocky Mountain J. Math. 33 (2003), 191-215.

[22] A. Shields AND D. Williams, Bounded projections, duality, and multipliers in spaces of analytic functions, Trans. Amer. Math. Soc. 162 (1971), 287-302.

[23] S. STEVIĆ, On an integral operator from the Zygmund space to the Bloch-type space on the unit ball, Glasg. J. Math. 51 (2009), 275-287.

[24] S. STEvić, Composition followed by differentiation from $H^{\infty}$ and the Bloch space to $n$th weightedtype spaces on the unit disk, Appl. Math. Comput. 216 (2010), 3450-3458.

[25] S. STEvić, Composition operators from the Hardy space to the $n$th weighted-type space on the unit disk and the half-plane, Appl. Math. Comput. 215 (2010), 3950-3955.

[26] S. STEVIĆ, On an integral-type operator from Zygmund-type spaces to mixed-norm spaces on the unit ball, Abstr. Appl. Anal. 2010 (2010), Article ID 198608, 7 pages.

[27] S. STEVIĆ, Weighted differentiation composition operators from $H^{\infty}$ and Bloch spaces to $n$th weigthed-type spaces on the unit disk, Appl. Math. Comput. 216 (2010), 3634-3641.

[28] S. STEVIĆ, Weighted differentiation composition operators from the mixed-norm space to the nth weigthed-type space on the unit disk, Abstr. Appl. Anal. vol. 2010 (2010), Article ID 246287, 15 pages.

[29] S. STEVIĆ, Weighted radial operator from the mixed-norm space to the nth weighted-type space on the unit ball, Appl. Math. Comput. 218 (2012), 9241-9247.

[30] M. TJANI, Compact composition operators on some Möbius invariant Banach space, $\mathrm{PhD}$ dissertation, Michigan State University, 1996.

[31] H. Wulan, D. Zheng And K. Zhu, Compact composition operators on BMOA and the Bloch space, Proc. Amer. Math. Soc. 137 (2009), 3861-3868.

[32] S. YE AND Q. Hu, Weighted composition operators on the Zygmund space, Abstr. Appl. Anal. 2012 (2012), Article ID 462482, 18 pages.

[33] X. Zhang AND J. XiaO, Weighted composition between $\mu$-Bloch spaces on the unit ball, Sci. China 48 (2005), 1349-1368.

[34] R. ZhaO, Essential norms of composition operators between Bloch type spaces, Proc. Amer. Math. Soc. 138 (2010), 2537-2546.

[35] K. ZHu, Operator Theory in Function Spaces, Marcel Dekker, New York and Basel, 1990.

[36] X. ZHU, Generalized weighted composition operators on Bloch-type spaces, J. Ineq. Appl. 2015 (2015), 59-68.

[37] X. ZHU, Essential norm of generalized weighted composition operators on Bloch-type spaces, Appl. Math. Comput. 274 (2016), 133-142. 